\title{
Assessment of Nitrogen Source, Sulfur, and Fall Fungicide Applications on the Management of Spring Dead Spot of Bermudagrass
}

\author{
D. J. Cottrill, D. T. Earlywine, and G. L. Miller, Division of Plant Sciences, University of Missouri, Columbia 65211
}

\begin{abstract}
Cottrill, D. J., Earlywine, D. T., and Miller, G. L. 2016. Assessment of nitrogen source, sulfur, and fall fungicide applications on the management of spring dead spot of bermudagrass. Plant Dis. 100:473-482.

Spring dead spot, caused by species of Ophiosphaerella, is the most serious disease of bermudagrass (Cynodon spp.) in regions where cold temperatures induce winter dormancy. Previous research indicates that soil $\mathrm{pH}$ reduction may reduce spring dead spot severity. Of the 165 isolates collected from 16 sites in Missouri and surrounding regions, Ophiosphaerella herpotricha was the most prominent spring dead spot pathogen found, with 154 confirmed isolates. Ten isolates were identified as $O$. korrae, being detected at a low incidence at 6 of 16 sites. In in vitro assays, most mycelial growth of both species occurred from $\mathrm{pH} 5$ to 6 ,

with more growth on calcium-nitrate-amended media than ammonium sulfate. In a naturally infested field study, nitrogen source alone did not affect spring dead spot severity. Less spring dead spot severity $(P<0.05)$ was observed in plots receiving tebuconazole but no treatment provided more than 38\% control after 1 year. Three sulfur applications (each at $98 \mathrm{~kg} \mathrm{ha}^{-1}$ ) provided as much control as a single fall tebuconazole application $\left(0.28 \mathrm{~kg}\right.$ a.i. ha $\left.{ }^{-1}\right)$ in the second year; however, significant phytotoxicity was observed in sulfur-treated plots thereafter. The suppression obtained from one fall tebuconazole treatment was as effective as two.
\end{abstract}

Spring dead spot is a destructive disease of bermudagrass (Cynodon dactylon (L.) Pers.) and hybrid cultivars (C. dactylon $\times$ C. transvaalensis Burtt-Davy) in geographic locations where freezing temperatures induce bermudagrass dormancy. Spring dead spot pathogens are soilborne fungi that colonize bermudagrass roots, rhizomes, and stolons (Tredway et al. 2009b; Walker and Smith 1972). Although pathogen infection and colonization occurs in cool soil temperatures $\left(<21^{\circ} \mathrm{C}\right)$ in fall and winter, symptoms do not appear until spring (Crahay et al. 1988; Endo et al. 1985; Tredway et al. 2009b; Walker et al. 2006). Sunken, bleached circular patches ( $3 \mathrm{~cm}$ to $>1 \mathrm{~m}$ in diameter) are prominent as uninfected bermudagrass resumes normal growth and comes out of winter dormancy. Belowground, dark runner hyphae are evident on infected roots and rhizomes, resulting in necrotic, black, and brittle plant structures. Symptoms are often more severe on highly maintained, 3- to 5-year-old bermudagrass swards (Tredway et al. 2009b).

Spring dead spot is caused by three species in the genus Ophiosphaerella: Ophiosphaerella herpotricha (Fr.) J. Walker; O. korrae (J. Walker \& A. M. Sm. bis.) Shoemaker and C. E. Babc.; and O. narmari (J. Walker \& A. M. Sm. bis.) H. C. Wetzel, Hubert \& Tisserat. Distribution of these pathogens is not uniform and may vary by geographical region in the United States. $O$. herpotricha is primarily found in the Midwest region, while $O$. korrae is the main spring dead spot pathogen species in the southeastern region of the United States and California (Crahay et al. 1988; Endo et al. 1985; Iriarte et al. 2004; Tisserat et al. 1989; Wetzel et al. 1999b). O. narmari has been occasionally isolated from infected bermudagrass tissue in Oklahoma, Kansas, North Carolina, and California but is not prevalent in the United States (Iriarte et al. 2004; Wetzel et al. 1999a). Although each species appears to have its primary location, some overlapping distribution does exist. $O$. herpotricha and $O$. korrae are often identified from the same site, and occasionally isolated from the same individual patch (Iriarte et al. 2004; Walker and Smith 1972; Wetzel et al. 1999b). Additionally, all three species have been detected from the same site in Oklahoma (Tredway et al. 2009b; Wetzel et al. 1999b).

Corresponding author: G. L. Miller; E-mail: turfpath@missouri.edu

Accepted for publication 17 August 2015.

http://dx.doi.org/10.1094/PDIS-05-15-0565-RE

(C) 2016 The American Phytopathological Society
Spring dead spot control is difficult because the infections occur belowground several months before symptom expression. Fungicides must be delivered below the thatch layer, an area of undecomposed plant material between leaves and soil surface (Iriarte et al. 2004). Once the disease becomes established, a combination of cultural and chemical practices is necessary in a multiyear approach to achieve acceptable spring dead spot control (Butler and Tredway 2006). Cultural practices include use of cold-tolerant bermudagrass varieties, core aerification, verticutting, soil $\mathrm{pH}$ manipulation, and nitrogen fertilization (Dernoeden et al. 1991; Tredway et al. 2009b; Vincelli 2014).

Reducing soil $\mathrm{pH}$ has been successful in suppression of soilborne diseases such as summer patch of Kentucky bluegrass (Poa pratensis L.) and take-all of wheat (Triticum spp.) of creeping bentgrass (Agrostis stolonifera L.) (Heckman et al. 2003; Smiley and Cook 1973; Thompson et al. 1995 ); Tredway et al. (2009a) reported ammonium sulfate applications reduced spring dead spot symptoms caused by $O$. herpotricha but not $O$. korrae. Conversely, calcium nitrate applications suppressed spring dead spot symptoms caused by $O$. korrae but not $O$. herpotricha. Dernoeden et al. (1991) also reported a reduction of spring dead spot symptoms caused by $O$. korrae as a result of ammonium sulfate applications, indicating that soil acidification may reduce severity. Nitrification inhibitors (dicyandiamide and others) reduce nitrate leaching by slowing the conversion of $\mathrm{NH}_{4}$ to $\mathrm{NO}_{3}$ (Mosdell et al. 1986). Therefore, nitrification inhibitors may be beneficial in cases where ammonium uptake and soil acidification suppress soilborne plant diseases (Hill et al. 2003; Mosdell et al. 1986; Smiley and Cook 1973).

Another method to reduce soil $\mathrm{pH}$ is through elemental sulfur applications. Vincelli (2014) reported sulfur applications reduced spring dead spot severity but may also delay emergence from winter dormancy (spring greenup). Lowering soil $\mathrm{pH}$ may also be important for increasing plant-available manganese $\left(\mathrm{Mn}^{2+}\right)$ in the soil. Manganese plays a crucial role in plant defense systems through cell detoxification and synthesis of cell wall lignin and phenolics (Alscher et al. 2002; Brown et al. 1984; Hill et al. 1999). The relationship between soil $\mathrm{pH}$ and spring dead spot occurrence may vary between site locations depending on soil type (Vincelli 2014).

Factors affecting fungicide efficacy include fungicide selection, application timing, and application method. Fungicide applications must be applied preventively during fall, before or during the infection period (Butler and Tredway 2006). Research indicates that fungicides with the ability to suppress spring dead spot include tebuconazole, 
propiconazole, benomyl, azoxystrobin, and myclobutanil (Butler and Tredway 2006 ; McCarty et al. 1992 ; Tredway et al. 2009b). Walker (2009) that reported two fall or one fall and one spring fungicide application of propiconazole offered the most effective and cost-effective disease control. Because spring dead spot pathogens are soilborne, the fungicide application must be either watered-in with post application irrigation or rainfall or applied in a high volume of water carrier.

A better understanding of the factors affecting spring dead spot occurrence and management is needed to develop more effective management practices for turfgrass managers. The objectives of this research were to provide additional evidence for the geographic distribution of spring dead spot pathogens and to investigate the impact of cultural practices and fungicide applications for spring dead spot control. The specific objectives were to (i) sample and assess the diversity of spring dead spot pathogens in the Midwest region, (ii) assess the impact of $\mathrm{pH}$ and nitrogen source on $O$. herpotricha and $O$. korrae in vitro, and (iii) evaluate the impact of nitrogen source, sulfur, nitrification inhibitors, and the fungicide tebuconazole on field spring dead spot symptoms caused by $O$. herpotricha.

\section{Materials and Methods}

Sampling and identification. Bermudagrass samples were collected at 16 locations exhibiting spring dead spot symptoms on golf course fairways, greens, and athletic fields in Missouri, Arkansas, and Kansas. At each site, the symptomatic area was defined, and samples were obtained from individual patches randomly selected along diagonal transects of the area. At each location, 10 to 20 cup cutter-sized samples $(10.75 \mathrm{~cm}$ in diameter by $10.16 \mathrm{~cm}$ in depth) were taken from the margin of necrotic spring dead spot patches.

Infected bermudagrass roots and rhizomes were cut into sections ( 5 to $10 \mathrm{~mm}$ in length), wrapped in cheesecloth, and continually rinsed with water for $30 \mathrm{~min}$. After rinsing, the sections were surface sterilized in a $0.06 \% \mathrm{NaOCl}$ solution for $5 \mathrm{~min}$ followed by submersion in an ethanol solution ( $70 \% \mathrm{vol} / \mathrm{vol})$ for $30 \mathrm{~s}$. The sections were then rinsed once with sterile water, blotted dry with a sterile paper towel, and plated on one-fourth-strength (9.75 g/liter) potato dextrose agar (PDA; Difco Laboratories, Detroit) amended with chloramphen$\operatorname{icol}\left(50 \mu \mathrm{g} \mathrm{ml}^{-1}\right)$, tetracycline $\left(50 \mu \mathrm{g} \mathrm{ml}^{-1}\right)$, and streptomycin sulfate $\left(50 \mu \mathrm{g} \mathrm{ml}^{-1}\right)$. For long-term storage prior to DNA extraction, isolates were placed on PDA slants (39 g/liter), incubated at room temperature for 7 days, covered with $5 \mathrm{ml}$ of light mineral oil (Thermo Fisher Scientific, Waltham, MA), and stored at $2^{\circ} \mathrm{C}$. Reference isolates of $O$. herpotricha and $O$. korrae were also obtained from the collection of L. Tredway (North Carolina State University, Raleigh).

Genomic DNA was extracted from 165 collected isolates and 2 reference isolates with the Easy-DNA kit (Invitrogen Corp., Carlsbad,
CA). Polymerase chain reaction (PCR) amplification of ribosomal (r) DNA internal transcribed spacer (ITS) regions ITS1, 5.8S rRNA, and ITS2 was conducted with the primer set ITS1f and ITS4 on all DNA extracts, according to previous protocols (Gardes and Bruns 1993; Henrion et al. 1992). Each PCR was $50 \mu l$ in volume and consisted of $10 \mu \mathrm{l}$ of MyTaq red reaction buffer (Bioline Inc., Taunton, MA), $200 \mathrm{nM}$ each primer, $0.25 \mu \mathrm{l}$ of Taq polymerase (Bioline Inc.), and 50 ng of genomic DNA. Thermal cycling conditions involved an initial denaturation step at $94^{\circ} \mathrm{C}$ for $1 \mathrm{~min}$; followed by 33 cycles of $94^{\circ} \mathrm{C}$ for $30 \mathrm{~s}, 65^{\circ} \mathrm{C}$ for $1 \mathrm{~min}$, and $72^{\circ} \mathrm{C}$ for $1 \mathrm{~min}$; and a final extension step at $72^{\circ} \mathrm{C}$ for $2 \mathrm{~min}$. Purification of amplified isolate DNA was performed using the QIAquick PCR Purification Kit (Qiagen Inc., Valencia, CA). Purified amplicons were taken to the University of Missouri DNA sequencing facility (Bond Life Sciences Center, University of Missouri, Columbia) for cleanup, electrophoresis, and sequencing.

The DNA sequence of each isolate was determined using the consensus of two reactions, one for each primer set. A BLAST search of GenBank was performed with each consensus sequence. For each sample, one or two of the most similar sequences based on maximal identity percentage were downloaded for comparison. All sequences were aligned using the MUSCLE method in MegAlign (12.2; DNASTAR Inc., Madison, WI) and adjusted by visual examination. A phylogenetic tree was constructed in MEGA 5.2 (Tamura et al. 2011) using the neighbor-joining algorithm from genetic distances calculated using the Kimura two-parameter model analysis. Bootstrap support at branch nodes was based on 1,000 random samples of the data set. Due to the similarity in sequences, Vascellum curtisii HQ235045 was used as an outgroup for trees examining the ITS region.

In vitro growth assays. The radial mycelial growth response to a range of $\mathrm{pHs}$ and two different nitrogen sources was determined for a subset of 42 isolates of $O$. herpotricha and 8 isolates of $O$. korrae. The affect of two different nitrogen sources on mycelial yield of $O$. herpotricha was also assessed. For all growth assays, petri plates (100 by $15 \mathrm{~mm}$; Thermo Fisher Scientific) and conical tubes $(50 \mathrm{ml}$; Corning Inc., Corning, NY) were arranged in four replications of a complete randomized design. The growth response for all isolates was determined in two repeated experimental runs.

For assessment of nitrogen impact on radial growth, a modified Melin-Norkrans (MMN) medium was utilized. The media contained $15 \mathrm{~g}$ of agar, $5 \mathrm{~g}$ of glucose, $0.5 \mathrm{~g}$ of $\mathrm{KH}_{2} \mathrm{PO}_{4}, 0.15 \mathrm{~g}$ of $\mathrm{MgSO}_{4}$, $50 \mathrm{mg}$ of $\mathrm{CaCl}_{2}, 25 \mathrm{mg}$ of $\mathrm{NaCl}$, and $12 \mathrm{mg}$ of $\mathrm{FeCl}_{3}$ per liter of distilled water delivered in a $1 \%$ (wt/vol) solution (Marx 1969). Yeast extract, malt extract, and ammonium phosphate were omitted to avoid utilization of nontarget nitrogen sources. Ammonium sulfate or calcium nitrate were amended as sole nitrogen sources to the

Table 1. Collection date, location, bermudagrass cultivar, and ribosomal DNA (rDNA) clade for sequences of Ophiosphaerella spp. obtained from bermudagrass exhibiting spring dead spot symptoms

\begin{tabular}{|c|c|c|c|c|}
\hline Collection date & Location & Bermudagrass cultivars & Number of sequenced isolates & Clade $^{\mathbf{a}}$ \\
\hline 21 May 2011 & Columbia, MO & Riviera, Patriot, Cody, SWI 2000, Sunrise & 44 & $\mathrm{~A}(n=43), \mathrm{C}(n=1)$ \\
\hline 28 April 2012 & Overland Park, KS & Unknown & 4 & $\mathrm{~A}(n=3), \mathrm{B}(n=1)$ \\
\hline 30 April 2012 & St. Louis, MO & Unknown & 14 & $\mathrm{~A}(n=11), \mathrm{B}(n=3)$ \\
\hline 9 May 2012 & Osage Beach, MO & Cheyenne & 11 & $\mathrm{~A}(n=10), \mathrm{B}(n=1)$ \\
\hline 15 May 2012 & Branson, MO & Mirage & 4 & $\mathrm{~A}(n=2), \mathrm{B}(n=2)$ \\
\hline 15 May 2012 & Branson, $\mathrm{MO}$ & Midlawn & 4 & $\mathrm{~A}(n=3), \mathrm{B}(n=1)$ \\
\hline 15 May 2012 & Branson, MO & Savannah & 4 & A \\
\hline 16 May 2012 & Fayetteville, AR & Patriot, Princess, Tifway, Riviera & 6 & A \\
\hline 16 May 2012 & Fayetteville, AR & Tifeagle & 6 & $4 \mathrm{~A}, 2 \mathrm{~B}$ \\
\hline 27 May 2012 & St. Louis, MO & Westwood & 10 & A \\
\hline 12 June 2012 & Columbia, MO & Riviera & 12 & A \\
\hline 21 June 2012 & St. Joseph, MO & Patriot & 7 & A \\
\hline 25 June 2012 & St. Louis, MO & Unknown & 8 & $\mathrm{~A}$ \\
\hline 21 May 2013 & Arnold, MO & Westwood & 12 & A \\
\hline 21 May 2013 & Park Hills, MO & Quickstand & 6 & A \\
\hline 6 June 2013 & Fenton, MO & Riviera & 13 & A \\
\hline Total & $\ldots$ & $\ldots$ & 165 & $\mathrm{~A}(n=154), \mathrm{B}(n=10), \mathrm{C}(n=1)$ \\
\hline
\end{tabular}

${ }^{a}$ Clade designated in phylogenetic tree found in Figure 1; $\mathrm{A}=$ O. herpotricha, $\mathrm{B}=O$. korrae, and $\mathrm{C}=$ O. narmari. 
medium prior to autoclaving at concentrations of 50, 100, 200, 400, or $800 \mu \mathrm{g} \mathrm{ml}^{-1}$. MMN media containing no nitrogen source was used as a control. All media were autoclaved for $30 \mathrm{~min}$, cooled to $55^{\circ} \mathrm{C}$, and poured into 100 -by-15-mm polystyrene petri plates. To assess $\mathrm{pH}$ impact, full-strength PDA (39 $\mathrm{g} /$ liter) was adjusted to a $\mathrm{pH}$ range of 3 through 9 prior to autoclaving using lactic acid $\left(\mathrm{C}_{3} \mathrm{H}_{6} \mathrm{O}_{3}\right)$ or sodium hydroxide $(\mathrm{NaOH})$. All $\mathrm{pH}$ measurements were recorded from 20 -ml aliquots mixed at $100 \mathrm{rpm}$ in a $50-\mathrm{ml}$ beaker with a $2.5-\mathrm{cm}$ magnetic stirring bar. Measurements were taken at room temperature with a precalibrated Accument AB15 pH meter (Thermo Fisher Scientific, Waltham, MA). All chemicals and supplies were obtained from Thermo Fisher Scientific.

Hyphal plugs (6 $\mathrm{mm}$ in diameter) from the edge of actively growing $O$. herpotricha and $O$. korrae colonies were homogenized in $5 \mathrm{ml}$ of sterile potato dextrose broth to provide a uniform suspension of mycelial fragments. A 5-mm-diameter agar plug was removed from the center of each plate to form a well in the solidified medium. Mycelial suspension $(50 \mu l)$ was transferred to the well in each of four replicate plates. Cultures were incubated at room temperature $\left(25^{\circ} \mathrm{C}\right)$, with radial growth measured at 12 days after plate inoculation. Radial growth was assessed as the average diameter of each colony measured in two perpendicular directions.

To assess nitrogen source impact on mycelial yield, hyphal plugs (6 $\mathrm{mm}$ in diameter) were excised from the edge of actively growing $O$. herpotricha isolates grown on $20 \mathrm{ml}$ of sterilized full-strength PDA. Plugs were placed in 50-ml polypropylene conical tubes (BD Biosciences, Durham, NC) containing $20 \mathrm{ml}$ of MMN media with the same ingredients as above, excluding agar. Nitrogen sources and concentrations were the same as those used in the solid media growth assay. Inoculated tubes were shaken at room temperature at $140 \mathrm{rpm}$ for 12 days. Mycelial plugs were harvested after 12 days by vacuum filtration onto preweighed filter paper $(7 \mathrm{~mm}$ in diameter; Thermo Fisher Scientific). Filter paper and mycelial plugs were dried at $40^{\circ} \mathrm{C}$ for $4 \mathrm{~h}$ and weighed. Initial filter paper weight was subtracted from final weight to obtain a yield of mycelial biomass. After several attempts, isolates of $O$. korrae would not grow in the liquid media. To assess potential $\mathrm{pH}$ changes from autoclaving, the $\mathrm{pH}$ of a 20-ml aliquot of each treatment was measured before and after autoclaving. Measurements of $\mathrm{pH}$ were also obtained at day 12 to assess the impact of mycelial growth on solution $\mathrm{pH}$.

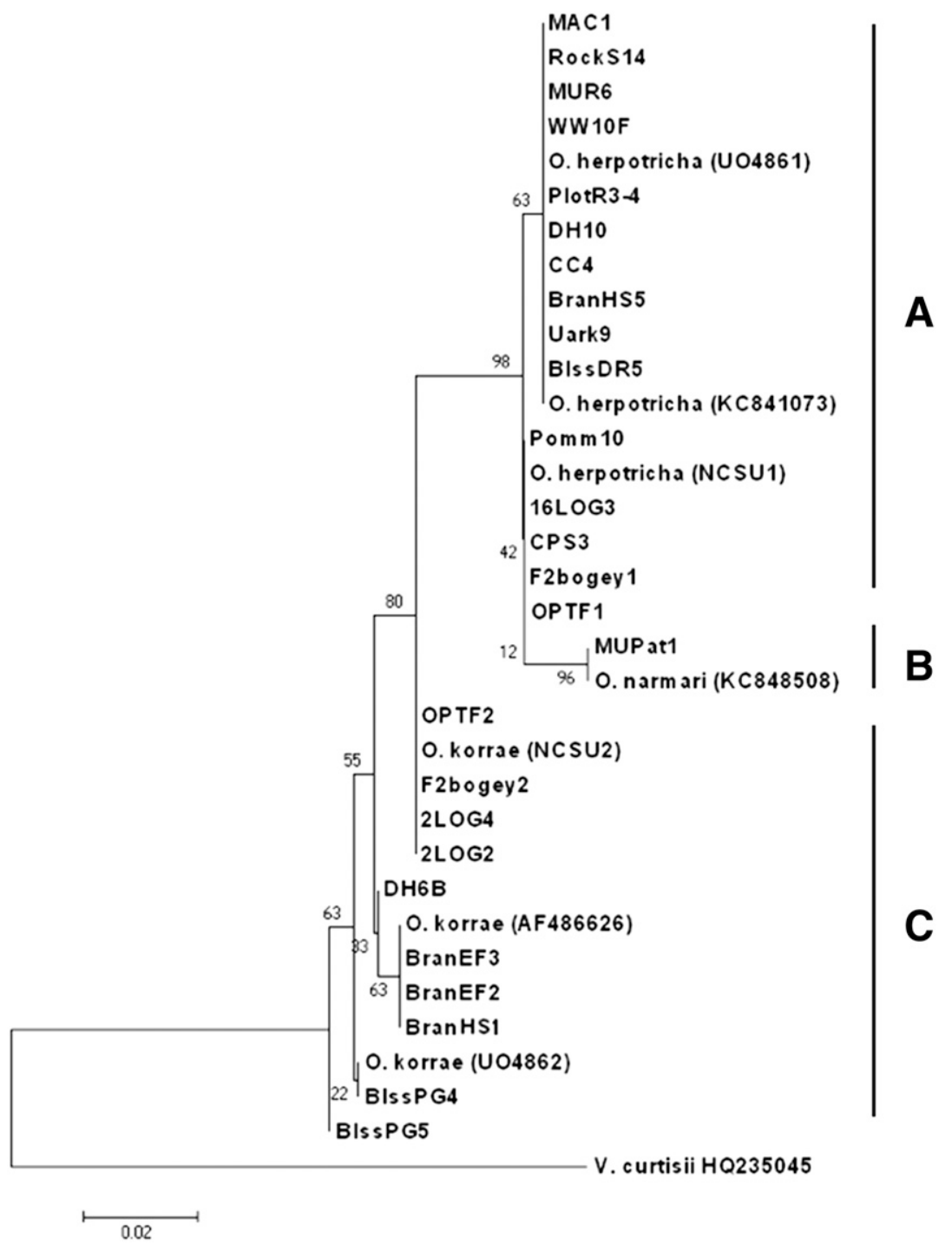

Fig. 1. Neighbor-joining phylogenetic tree of Ophiosphaerella spp. produced from sequences of ribosomal DNA (rDNA) regions: partial nuclear small-subunit rDNA, internal transcribed spacer (ITS)1, 5.8S, ITS2, and partial nuclear large subunit rDNA. Isolates either were recovered from Missouri and surrounding regions from bermudagrass exhibiting spring dead spot symptoms or were reference isolates obtained from L. Tredway (North Carolina State University, Raleigh). Letters indicate the clades containing known Ophiosphaerella spp. found in this study. Additional sequences from recovered isolates $(n=139)$ are collapsed into clade A and not shown. Scale bar indicates the horizontal distance corresponding to genetic distance as calculated by the Kimura two-parameter model. Bootstrap values are indicated adjacent to nodes and are based on 1,000 resamplings of the data set. 
The reproducibility of the radial mycelial growth and mycelial yield assay procedures was also assessed. For the radial growth assay, two isolates of $O$. herpotrich $a$ and $O$. korrae were arbitrarily selected from the collection of 42 and 8 isolates, respectively. For the mycelial yield assay, the same two $O$. herpotricha isolates were used. Response to calcium nitrate at $100 \mu \mathrm{g} \mathrm{ml}^{-1}$ and ammonium sulfate at $100 \mu \mathrm{g} \mathrm{ml}^{-1}$ was determined for all isolates in five separate repeated runs. The mean values, standard deviation, variance, coefficient of variance, and $95 \%$ confidence intervals were calculated for each isolate.

Least square means for radial mycelial growth and mycelial yield were subjected to analysis of variance (ANOVA) using the PROC MIXED procedure in SAS (version 9.2; SAS Institute, Cary, NC). Least square means were separated by pairwise comparisons performed using the LSmeans command $(\alpha=0.05)$.

Naturally infested field trial. A 3-year field experiment was initiated in 2011 to assess the impact of curative applications of nitrogen source, sulfur, and tebuconazole applications on spring dead spot severity. The experiment was conducted at the University of Missouri Turfgrass Field Research Farm in Columbia. The study

Table 2. Mycelial growth of Ophiosphaerella spp. as affected by $\mathrm{pH}$ and nitrogen source ${ }^{\mathrm{a}}$

\begin{tabular}{|c|c|c|c|}
\hline Growth assessment, treatment ${ }^{b}$ & $\begin{array}{l}\text { Concentration } \\
\left(\mu \mathrm{g} \mathrm{ml}^{-1}\right)^{\mathrm{c}}\end{array}$ & $\mathbf{p H}, \mathbf{P A}^{\mathrm{d}}$ & $\mathbf{p H}, \mathbf{P H}^{\mathrm{e}}$ \\
\hline \multicolumn{4}{|l|}{$\mathrm{pH}$} \\
\hline 3 & $\ldots$ & 2.86 & $\ldots$ \\
\hline 4 & $\ldots$ & 3.81 & $\ldots$ \\
\hline 5 & $\ldots$ & 4.94 & $\ldots$ \\
\hline 6 & $\ldots$ & 6.06 & $\ldots$ \\
\hline 7 & $\ldots$ & 6.95 & $\ldots$ \\
\hline 8 & $\ldots$ & 7.64 & $\ldots$ \\
\hline 9 & $\ldots$ & 8.37 & $\ldots$ \\
\hline \multicolumn{4}{|l|}{ Nitrogen source: Solid } \\
\hline \multirow[t]{6}{*}{$\left(\mathrm{NH}_{4}\right)_{2} \mathrm{SO}_{4}$} & 0 & 6.14 & $\ldots$ \\
\hline & 50 & 6.12 & $\ldots$ \\
\hline & 100 & 6.12 & $\ldots$ \\
\hline & 200 & 6.08 & $\ldots$ \\
\hline & 400 & 5.96 & $\ldots$ \\
\hline & 800 & $\ldots$ & - \\
\hline \multirow[t]{6}{*}{$\mathrm{CaNO}_{3}$} & 0 & $\ldots$ & - \\
\hline & 50 & $\ldots$ & - \\
\hline & 100 & $\ldots$ & - \\
\hline & 200 & $\ldots$ & - \\
\hline & 400 & $\ldots$ & - \\
\hline & 800 & $\ldots$ & - \\
\hline \multicolumn{4}{|l|}{ Nitrogen source: Liquid } \\
\hline \multirow[t]{6}{*}{$\left(\mathrm{NH}_{4}\right)_{2} \mathrm{SO}_{4}$} & 0 & 5.66 & 5.52 \\
\hline & 50 & 5.42 & 4.13 \\
\hline & 100 & 5.47 & 4.16 \\
\hline & 200 & 5.41 & 3.60 \\
\hline & 400 & 5.36 & 3.54 \\
\hline & 800 & 5.52 & 3.56 \\
\hline \multirow[t]{6}{*}{$\mathrm{CaNO}_{3}$} & 0 & 5.66 & 5.52 \\
\hline & 50 & 5.48 & 5.73 \\
\hline & 100 & 5.57 & 5.88 \\
\hline & 200 & 5.63 & 5.93 \\
\hline & 400 & 5.43 & 6.00 \\
\hline & 800 & 5.49 & 6.16 \\
\hline
\end{tabular}

a Measurements of $\mathrm{pH}$ in growth media taken before and after autoclaving, and post mycelium harvest of $O$. herpotrich $a$ in the amended liquid media.

${ }^{\mathrm{b}}$ For $\mathrm{pH}$ treatments, lactic acid or sodium hydroxide was added to potato dextrose agar to target level $\mathrm{pH}$ prior to autoclaving. Ammonium sulfate or calcium nitrate was added to either solid or liquid media prior to autoclaving at the noted concentration.

${ }^{c}$ Concentration of either ammonium sulfate or calcium nitrate.

${ }^{\mathrm{d}}$ Measurement of media solution $\mathrm{pH}$ post autoclaving.

e Measurement of media solution $\mathrm{pH}$ post mycelium harvest (liquid media only). was performed on a 'Riviera' bermudagrass research plot on a Mexico silt loam soil with an initial $\mathrm{pH}$ of 5.5 to 5.7 , as measured from six random samples taken throughout the plot area in 2010. A natural occurrence of spring dead spot symptoms was observed across the plot area prior to trial initiation. The site was mowed at $1.9 \mathrm{~cm}$ three times a week and irrigated as needed to prevent drought stress. Plots were 1.5 by $3 \mathrm{~m}$, and arranged in a strip-split plot design with five replications. Nitrogen source was the main plot (strips) and sulfur and fungicide treatments were the subplots. Plots were not rerandomized between years to assess multiyear treatment affects. To determine the Ophiosphaerella spp. causing symptoms in the experimental plot, six cup-cutter-sized samples $(10.75 \mathrm{~cm}$ wide by $10.16 \mathrm{~cm}$ in depth) were collected at random from each replication for a total of 30 samples. Samples were then speciated as stated previously by ITS sequence analysis.

On 20 October 2010, initial bulk soil pH and nutrient analysis was conducted on six samples taken randomly across the plot in diagonal transects. Bulk soil pH was determined on 5 September 2011, 30 May 2013, and 22 August 2013 by pulling one soil core $(1.9 \mathrm{~cm}$ wide by $7.62 \mathrm{~cm}$ deep) from each plot, and bulking the five replicates together to obtain one representative soil sample for each treatment $(n=30)$. Soil $\mathrm{pH}$ was measured for each sample in a 1:2 (wt/vol) suspension of $10 \mathrm{~g}$ of soil in $0.01 \mathrm{M} \mathrm{CaCl}_{2}$. Measurements were taken at room temperature with a precalibrated Accument $\mathrm{AB} 15$ pH meter (Thermo Fisher Scientific). Samples were also sent to MicroMacro Analytical Laboratory (Athens, GA) for bulk soil pH measurement and soil elemental analysis with inductively coupled plasma emission spectrometry (Soltanpour et al. 1996). To determine irrigation water $\mathrm{pH}$, six samples $(50 \mathrm{ml})$ of irrigation water were collected on 8 June 2012 in 50-ml polypropylene conical tubes (BD Biosciences) directly from irrigation heads and measured.

Treatments were initiated 10 June 2011. Nitrogen source treatments included urea, ammonium sulfate, calcium nitrate, UMAXX, and UFLEXX applied at a rate of $\mathrm{N}$ at $49 \mathrm{~kg} \cdot \mathrm{ha}^{-1}$ once a month in June, July, and August using a 91.4-cm-wide drop spreader (The Gandy Company, Owatonna, MN). UMAXX and UFLEXX (Agrotain International, St. Louis) contain the urease inhibitor $\mathrm{N}$-(n-butyl) thiophosphoric triamide and the nitrification inhibitor dicyandiamide. Flowers of sulfur (MFA Inc., Columbia, MO) were applied at $98 \mathrm{~kg} \mathrm{ha}^{-1}$ using a hand broadcast spreader at the same time as nitrogen. Tebuconazole (Torque; Cleary Chemicals LLC, Dayton, NJ) was applied at $0.82 \mathrm{~kg}$ a.i. ha ${ }^{-1}$ either once per annum on 14 October or twice per annum on 16 September and 14 October. Tebuconazole was applied in water equivalent to 7.57 liters per $92.9 \mathrm{~m}^{2}$ with a $\mathrm{CO}_{2}$-powered sprayer calibrated to $172 \mathrm{kPa}$ using TeeJet 8008 nozzles. All nutrient and fungicide treatments were watered in with 5 to $6 \mathrm{~mm}$ of overhead irrigation water immediately after application.

To establish a baseline disease severity for each plot, disease severity was assessed on 10 Jun 2011 before the trial was initiated $\left(\mathrm{Y}_{0}\right)$. Disease symptoms were most evident in the plot area during complete greenup of uninfected bermudagrass, which occurred on 22 May or 23 May in all 3 years. Percent control was calculated as $\mathrm{Y}_{0}-\mathrm{Y}_{i} / \mathrm{Y}_{\mathrm{o}}$, where $\mathrm{Y}_{i}=$ disease severity on 22 May 2012, 23 May 2013, or 23 May 2014.

Disease assessment. Visual disease severity ratings were taken for all field trials by estimating the percentage of foliar spring dead spot symptoms in a single plot. Digital images were also obtained on 10 June 2011, 22 May, 8 June, and 22 June 2012; 23 May, 10 June, and 24 June in 2013; and 23 May, 6 June, and 20 June in 2014. Images of each plot were taken with a D90 Nikon DSLR camera (Nikon Inc., Mellville, NY) mounted on a monopod constructed of 3.1-cm-wide vertical and horizontal square aluminum tubing. The vertical tubing was $3 \mathrm{~m}$ high and the horizontal section $(0.8 \mathrm{~m}$ long) was fastened to the top and center of the vertical section at a $90^{\circ}$ angle so the camera was centered directly above the plot area. A $30.5-\mathrm{cm}$ horizontal guide was attached at the bottom so pictures would be taken at the same location in each plot. Horizontal and vertical levels were mounted to the vertical tubing of the monopod to ensure the monopod was directly upright. The camera was 
mounted to the top horizontal section facing down with a standard tripod screw.

Before digital photography was conducted, all plot borders were outlined with cotton string. The camera was set to fully automatic mode; therefore, flash and shutter speed adjusted according to light conditions. Pictures were taken from 0800 to $1130 \mathrm{~h}$ to avoid shadows cast from the monopod. Images were analyzed using SigmaScan Pro 5.0 (Systat Software, Inc., Point Richmond, CA) using image editing and batch analysis macros designed by Karcher and Richardson $(2003$, 2005). Before analysis, all pictures were manually cropped to the plot borders and set to the same pixel size $(1,600$ by $1,200)$, color hue (40 to 100), and saturation (0 to 100) values.

Data were subject to ANOVA performed in SAS 9.2 (SAS Institute) using the PROC MIXED procedure, with year as a fixed effect. Least

Table 3. Reproducibility of the growth assays performed for determining nitrogen source impact on radial growth of Ophiosphaerella herpotricha and $O$. korrae, and mycelial yield of $O$. herpotricha

\begin{tabular}{|c|c|c|c|c|}
\hline \multirow[b]{2}{*}{ Assay } & \multirow[b]{2}{*}{ Isolate $^{\mathbf{a}}$} & \multicolumn{3}{|c|}{ Diameter and weight } \\
\hline & & Mean $^{b}$ & $\mathrm{CI}^{\mathrm{c}}$ & $\overline{C V}(\%)^{d}$ \\
\hline \multicolumn{5}{|c|}{ Radial growth (mm) } \\
\hline \multirow[t]{4}{*}{$(\mathrm{NH} 4)_{2} \mathrm{SO}_{4}$} & OPTF4 (O.h.) & 26.20 & $24.64-27.75$ & 0.06 \\
\hline & CTC8 (O.h.) & 22.10 & $21.31-22.88$ & 0.04 \\
\hline & 2LOG3 (O.k.) & 24.80 & $23.51-26.08$ & 0.05 \\
\hline & OPTF2 (O.k.) & 23.70 & $22.22-25.17$ & 0.07 \\
\hline \multirow[t]{4}{*}{$\mathrm{CaNO}_{3}$} & OPTF4 (O.h.) & 48.8 & $46.58-51.01$ & 0.02 \\
\hline & CTC8 (O.h.) & 52.3 & $51.44-53.15$ & 0.01 \\
\hline & 2LOG3 (O.k.) & 71.6 & $70.28-72.91$ & 0.01 \\
\hline & OPTF2 (O.k.) & 57.3 & $56.7-57.91$ & 0.01 \\
\hline \multicolumn{5}{|c|}{ Mycelial yield (mg) } \\
\hline \multirow[t]{2}{*}{$(\mathrm{NH} 4)_{2} \mathrm{SO}_{4}$} & WW9f (O.h.) & 6.92 & $6.52-7.36$ & 0.06 \\
\hline & DH10 (O.h.) & 6.86 & $6.57-7.11$ & 0.04 \\
\hline \multirow[t]{2}{*}{$\mathrm{CaNO}_{3}$} & WW9f (O.h.) & 15.24 & $14.62-15.86$ & 0.04 \\
\hline & DH10 (O.h.) & 15.42 & $15.22-15.61$ & 0.01 \\
\hline
\end{tabular}

a O.h. = Ophiosphaerella herpotricha and O.k. $=$ O. korrae.

$\mathrm{b}$ Mean radial growth values based upon values obtained in five repeated assays.

c The 95\% confidence intervals based upon values collected.

${ }^{\mathrm{d}}$ Coefficient of variances based upon values collected. square means were separated with Tukey's test $(\alpha=0.05)$. Area under the disease progress curve (AUDPC) was calculated with the formula $\Sigma\left[\left(y^{i}+y^{i}+1\right) / 2\right]\left[t^{i}+1-t^{i}\right]$, where ${ }^{i}=1,2,3, \ldots n-1 ; y^{i}$ is the percent diseased plot area, and $t^{i}$ is the time of the $i$ th rating (Shaner and Finney 1977). Correlation analysis was conducted using the PROC CORR procedure in SAS 9.2 to compare the two disease estimation methods.

\section{Results}

Species distribution. Of the 213 fungi isolated from symptomatic tissue, 165 were putative Ophiosphaerella spp. and speciated by sequence similarity of the ITS region to GenBank accessions and reference isolates (Table 1; Fig. 1). Sequenced isolates had ITS amplicons of 535 to $600 \mathrm{bp}$ in size and were 98 to $99 \%$ similar to the reference isolates of $O$. herpotricha and $O$. korrae, and the GenBank accessions of either $O$. herpotricha (KC841073, U04861), O. korrae (AF486626, UO4862), or O. narmari (KC848508). O. herpotricha was discovered at each site and made up $93 \%$ of the isolates $(n=154)$. O. korrae was isolated from six locations and made up 6\% of the isolates $(n=10)$. Only one isolate of $O$. narmari was found, originating from a 'Patriot' bermudagrass research plot at the University of Missouri Turfgrass Research Farm in Columbia. O. herpotricha and $O$. korrae were isolated once from the same turfgrass sample.

In vitro mycelial growth assay. Radial mycelial growth was greater for $O$. korrae than $O$. herpotricha in $\mathrm{pH}$ and solid nitrogen media assessments $(P<0.0001)$. The $\mathrm{pH}$ of the modified PDA used in the $\mathrm{pH}$ experiment changed \pm 0.14 to 0.63 after autoclaving. The $\mathrm{pH}$ of MMN media used in the solid nitrogen source assay was similar across all treatments before and after autoclaving. Similar to solid media, the $\mathrm{pH}$ of amended liquid MMN media was similar across all treatments at the beginning of the experiment. At harvest, however, $\mathrm{pH}$ increased as calcium nitrate concentration increased and decreased as ammonium sulfate concentrations increased (Table 2).

For the two isolates of $O$. herpotricha and $O$. korrae evaluated in five repeated runs of the radial growth assay, the coefficients of variance for each isolate ranged from 0.01 to $0.07 \%$ (Table 3). The $95 \%$ confidence intervals ranged from 94 to $106 \%$ of the mean radial growth value for individual isolates subjected to the assay. For the two $O$. herpotricha isolates evaluated in five repeated runs of the mycelial weight assay, the coefficient of variance for each isolates ranged from 0.01 to $0.06 \%$. The $95 \%$ confidence intervals ranged

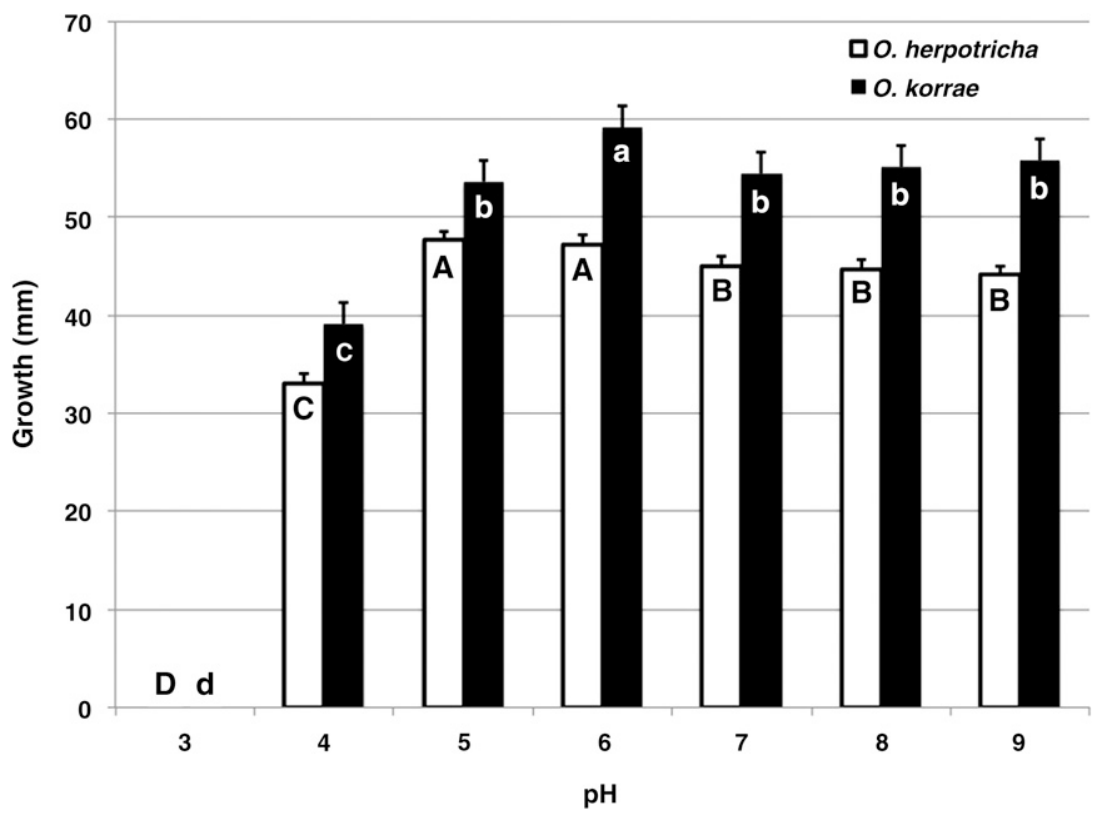

Fig. 2. Growth of Ophiosphaerella herpotricha and $\mathrm{O}$. korrae after 12 days on potato dextrose agar adjusted to a pH range of 3 to 9 with $\mathrm{NaOH}$ or lactic acid. No growth occurred on media amended to $\mathrm{pH}$ 3. Within species, columns with the same letter are not statistically different according to pairwise comparisons of least square means $(P=0.05)$. Least square means are averaged across all isolates. Error bars represent the standard error of the means. 
from 94 to $107 \%$ of the mean radial growth value for individual isolates subjected to the assay.

Effect of pH on mycelial growth. Radial mycelial growth was significantly influenced by $\mathrm{pH}(P<0.0001)$. No growth was recorded for either species at $\mathrm{pH} 3$. Growth was significantly lower for both species at $\mathrm{pH} 4$ compared with higher $\mathrm{pH}$ treatments $(P<0.0001)$. Radial growth of $O$. korrae was significantly higher $(+3.36$ to $20.04 \mathrm{~mm})$ at $\mathrm{pH} 6$ than other $\mathrm{pH}$ treatments $(P \leq 0.015$; Fig. 2$)$. Growth of $O$. korrae was not significantly different among $\mathrm{pH}$ treatments of 5, 7, 8, and $9(P>0.05)$. Radial growth of $O$. herpotricha was significantly higher ( +1.76 to $13.84 \mathrm{~mm})$ on $\mathrm{pH}$ treatments of 5 and 6 than other $\mathrm{pH}$ treatments $(P \leq 0.014$; Fig. 2$)$. Growth was not significantly different for $O$. herpotricha among $\mathrm{pH}$ treatments of 7,8 , and $9(P>0.05)$.

Nitrogen source. Nitrogen source and concentration significantly affected radial growth on liquid amended media $(P<0.0001)$. Radial mycelial growth of $O$. herpotricha and $O$. korrae isolates was greater on calcium-nitrate-amended MMN media than on ammonium sulfate $(P<0.0001)$. No differences in radial growth of $O$. korrae were observed among calcium-nitrate-amended media concentrations. Little differences in growth of $O$. herpotricha on calcium-nitrateamended media were observed, with only growth on calcium nitrate at $800 \mu \mathrm{g} \mathrm{ml}^{-1}$ being significantly lower $(-2.07$ to $3.16 \mathrm{~mm})$ than other treatments $(P \leq 0.016)$. Radial growth of $O$. korrae was significantly lower on MMN media amended with ammonium sulfate at $100,200,400$, and $800 \mu \mathrm{g} \mathrm{ml}^{-1}$ compared with ammonium sulfate at $50 \mu \mathrm{g} \mathrm{ml}^{-1}$ and no nitrogen $(P<0.0001$; Fig. 3). Similarly, radial growth of $O$. herpotricha was highest on $50 \mu \mathrm{g} \mathrm{ml}^{-1}$, with growth lowest on 200, 400, and $800 \mu \mathrm{g} \mathrm{ml}^{-1}$ ( $P \leq 0.001$; Fig. 3).

Nitrogen source and concentration had a significant affect on mycelial yield after 12 days of incubation $(P<0.0001)$. Treatments with no nitrogen amendment weighed significantly less $(-3.77$ to $7.23 \mathrm{mg})$ than all nitrogen-amended treatments $(P<0.0001$; Fig. 4$)$. Similar to the radial growth response in solid media, $O$. herpotricha weighed significantly more (+1.45 to $3.44 \mathrm{mg}$ ) after 12 day of incubation in liquid amended with calcium nitrate than ammonium sulfate $(P<0.0001)$. Mycelial yield of $O$. herpotricha was greater in liquid media amended with calcium nitrate at $800 \mu \mathrm{g} \mathrm{ml}^{-1}$ than
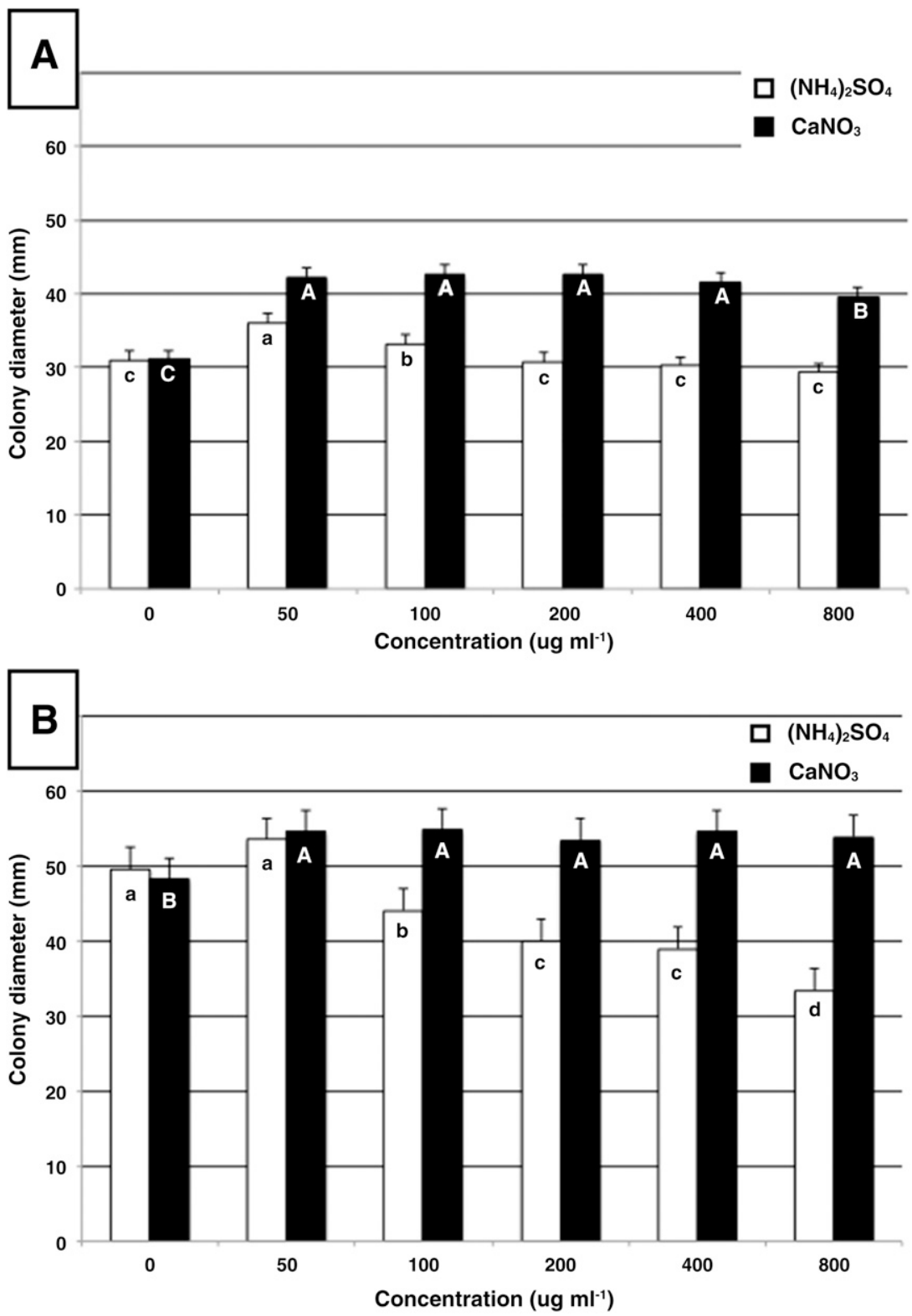

Fig. 3. Growth of A, Ophiosphaerella herpotricha and B, 0 . korrae on modified Melin-Norkrans medium amended with either ammonium sulfate or calcium nitrate at 0 to $800 \mu \mathrm{g} \mathrm{ml}^{-1}$. Within nitrogen source, columns with the same letter are not statistically different according to pairwise comparisons performed in SAS using the LSmeans command $(\alpha=0.05)$. Least square means are averaged across all isolates. Error bars represent the standard error of the means. 
unamended or with calcium nitrate treatments at 50 or $200 \mu \mathrm{g} \mathrm{ml}^{-1}$ $(P \leq 0.025)$ but not significantly different than calcium nitrate treatments of 100 or $400 \mu \mathrm{g} \mathrm{ml}^{-1}(P \geq 0.071)$ (Fig. 4). Mycelial yield of $O$. herpotricha was higher in ammonium sulfate at $200 \mu \mathrm{g} \mathrm{ml}^{-1}$ than at $100 \mu \mathrm{g} \mathrm{ml}^{-1}(P=0.019)$ but not significantly different from other ammonium sulfate treatments (Fig. 4).

Field study. Initial bulk soil pH on October 2010 averaged 5.36. In subsequent analysis, plots receiving sulfur averaged a $\mathrm{pH}$ of 5.52, which was slightly lower than plots not receiving sulfur (5.61). No substantial differences were observed in any soil nutrient levels between analyses conducted on 20 October 2012, 30 May 2013, or 22 August 2013 (data not shown). Irrigation water $\mathrm{pH}$ was slightly alkaline (7.5 to 8.0). All 30 isolates of Ophiosphaerella spp. recovered from the field site had ITS amplicons of 535 to $591 \mathrm{bp}$ in size and were 98 to $99 \%$ similar to the GenBank accession of $O$. herpotricha (U04861).

A significant difference between years $(P<0.0001)$ was observed for both digital image analysis and visual estimates of disease severity; therefore, data from each year were analyzed separately.
For each rating date, Pearson's correlation coefficient $(r)$ between severity determined from visual ratings and digital imaging analysis ranged from 0.286 to 0.902 and averaged 0.640 (Table 4). Correlation became weaker at later rating dates, due to visual differentiation between sulfur phytotoxicity and spring dead spot symptoms that wasn't discerned in digital image analysis. During periods of high disease severity, visual estimates were consistently higher than estimates obtained from digital imaging analysis.

Nitrogen source did not have a significant effect on spring dead spot severity. On 22 May 2012, sulfur treatments significantly reduced spring dead spot severity $(P=0.0127)$ and in 2013 reduced AUDPC $(P<0.0001)$ (Table 4$)$. A significant interaction of nitrogen source and sulfur occurred in May 2013 and 2014, as estimated with digital image analysis (Table 4). Delayed spring greenup was observed on 23 May 2013 in plots receiving both ammonium sulfate and sulfur. On 23 May 2014, all plots receiving sulfur were delayed in spring greenup, with ammonium sulfate being most affected. In both years, digital image analysis was unable to discern between dormant and diseased turf during the spring greenup period (Fig. 5).

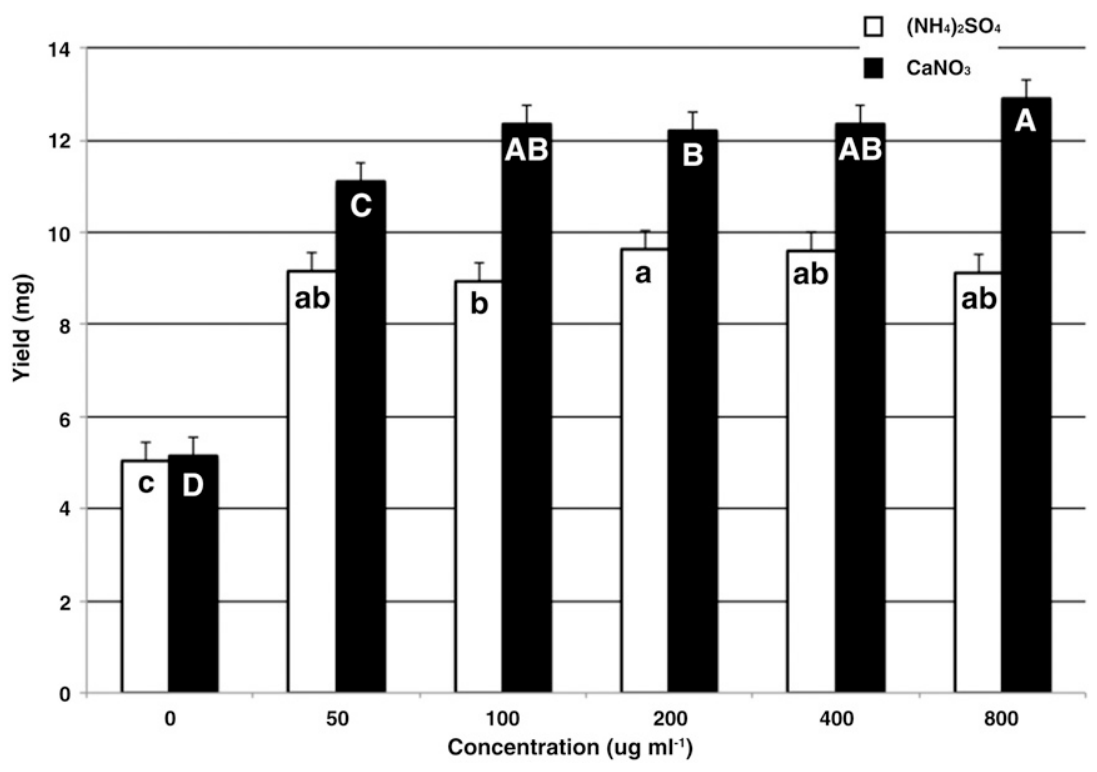

Fig. 4. Yield of Ophiosphaerella herpotricha mycelium in liquid Melin-Norkrans medium amended with either ammonium sulfate or calcium nitrate at 0-800 $\mu \mathrm{g} \mathrm{ml}{ }^{-1}$. Within nitrogen source, columns with the same letter are not significantly different according to pairwise comparisons performed in SAS using the LSmeans command $(\alpha=0.05)$. Means are averaged across all isolates. Error bars represent the standard error of the means.

Table 4. Results of analysis of variance for field experiment to determine the effects of nitrogen source, sulfur, and fungicide on curative control of spring dead spot caused by Ophiosphaerella herpotrich $a^{\mathrm{a}}$

\begin{tabular}{|c|c|c|c|c|c|c|c|c|c|c|c|c|c|}
\hline & & \multicolumn{6}{|c|}{ Individual rating dates ${ }^{b}$} & \multicolumn{6}{|c|}{ AUDPC $^{c}$} \\
\hline & & \multicolumn{2}{|c|}{22 May 2012} & \multicolumn{2}{|c|}{23 May 2013} & \multicolumn{2}{|c|}{23 May 2014} & \multicolumn{2}{|c|}{2012} & \multicolumn{2}{|c|}{2013} & \multicolumn{2}{|c|}{2014} \\
\hline & & DIA & Visual & DIA & Visual & DIA & Visual & DIA & Visual & DIA & Visual & DIA & Visual \\
\hline Source $^{d}$ & df & $\operatorname{Pr}>F$ & $\operatorname{Pr}>F$ & $\operatorname{Pr}>F$ & $\operatorname{Pr}>F$ & $\operatorname{Pr}>F$ & $\operatorname{Pr}>F$ & $\operatorname{Pr}>F$ & $\operatorname{Pr}>F$ & $\operatorname{Pr}>F$ & $\operatorname{Pr}>F$ & $\operatorname{Pr}>F$ & $\overline{\operatorname{Pr}>F}$ \\
\hline Nitrogen source & 4 & 0.568 & 0.865 & 0.809 & 0.921 & 0.036 & 0.694 & 0.699 & 0.906 & 0.533 & 0.704 & 0.001 & 0.704 \\
\hline Fungicide & 2 & 0.001 & 0.089 & $<0.001$ & 0.007 & 0.200 & 0.606 & $<0.0001$ & $<0.0001$ & $<0.0001$ & $<0.0001$ & $\mathbf{0 . 0 3 7}$ & 0.022 \\
\hline Nitrogen source $\times$ fungicide & 8 & 0.910 & 0.073 & 0.884 & 0.936 & 0.988 & 0.399 & $<0.0001$ & 0.066 & 0.593 & 0.055 & 0.949 & 0.378 \\
\hline Sulfur $(S)$ & 1 & 0.013 & 0.004 & 0.418 & 0.010 & 0.003 & 0.092 & 0.057 & 0.007 & $<0.0001$ & $<0.0001$ & $<0.001$ & 0.043 \\
\hline Nitrogen source $\times S$ & 4 & 0.805 & 0.748 & 0.018 & 0.078 & $<0.0001$ & 0.464 & 0.215 & 0.576 & 0.180 & 0.537 & $<0.0001$ & 0.372 \\
\hline Fungicide $\times \mathrm{S}$ & 2 & 0.786 & 0.881 & 0.534 & 0.984 & 0.675 & 0.488 & 0.158 & 0.557 & 0.025 & 0.090 & 0.532 & 0.43 \\
\hline Nitrogen source $\times$ fungicide $\times S$ & 8 & 0.810 & 0.749 & 0.436 & 0.697 & 0.995 & 0.541 & 0.763 & 0.883 & 0.711 & 0.974 & 0.372 & 0.458 \\
\hline
\end{tabular}

a $P$ values calculated with the PROC GLIMMIX procedure. Significant values $(P<0.05)$ indicated in bold.

b Individual ratings taken on dates when spring dead spot symptoms were first prominent after uninfected bermudagrass emerged from dormancy. Ratings were obtained through either digital image analysis (DIA) or by visual estimation of the percent spring dead spot in the plot area.

${ }^{c}$ Area under the disease progress curve (AUDPC) for each year of the study calculated with the trapezoidal rule (Shaner and Finney 1977).

${ }^{\mathrm{d}}$ Factors of the field experiment. Nitrogen source $=$ urea, calcium nitrate, ammonium sulfate, UFLEXX, or UMAXX applied with $\mathrm{N}$ at $49 \mathrm{~kg} \mathrm{ha}^{-1}$ in June, July, and August; Fungicide $=$ tebuconazole $\left(0.82 \mathrm{~kg}\right.$ a.i. ha $\left.{ }^{-1}\right)$ applied either once or twice per fall; and $\mathrm{S}=$ flowers of sulfur applied at $98 \mathrm{~kg} \mathrm{ha}{ }^{-1}$ in June, July, and August. 
Fungicide treatments significantly reduced AUDPC in each year and on most rating dates (Table 4). Plots treated with tebuconazole either once or twice had lower AUDPC values in 2012 than untreated plots without sulfur treatment (Fig. 6). In 2013, the
AUDPC of plots treated with one tebuconazole application with and without sulfur, or two applications without sulfur, were not significantly different from plots treated with sulfur alone. In all 3 years, no significant difference in spring dead spot severity

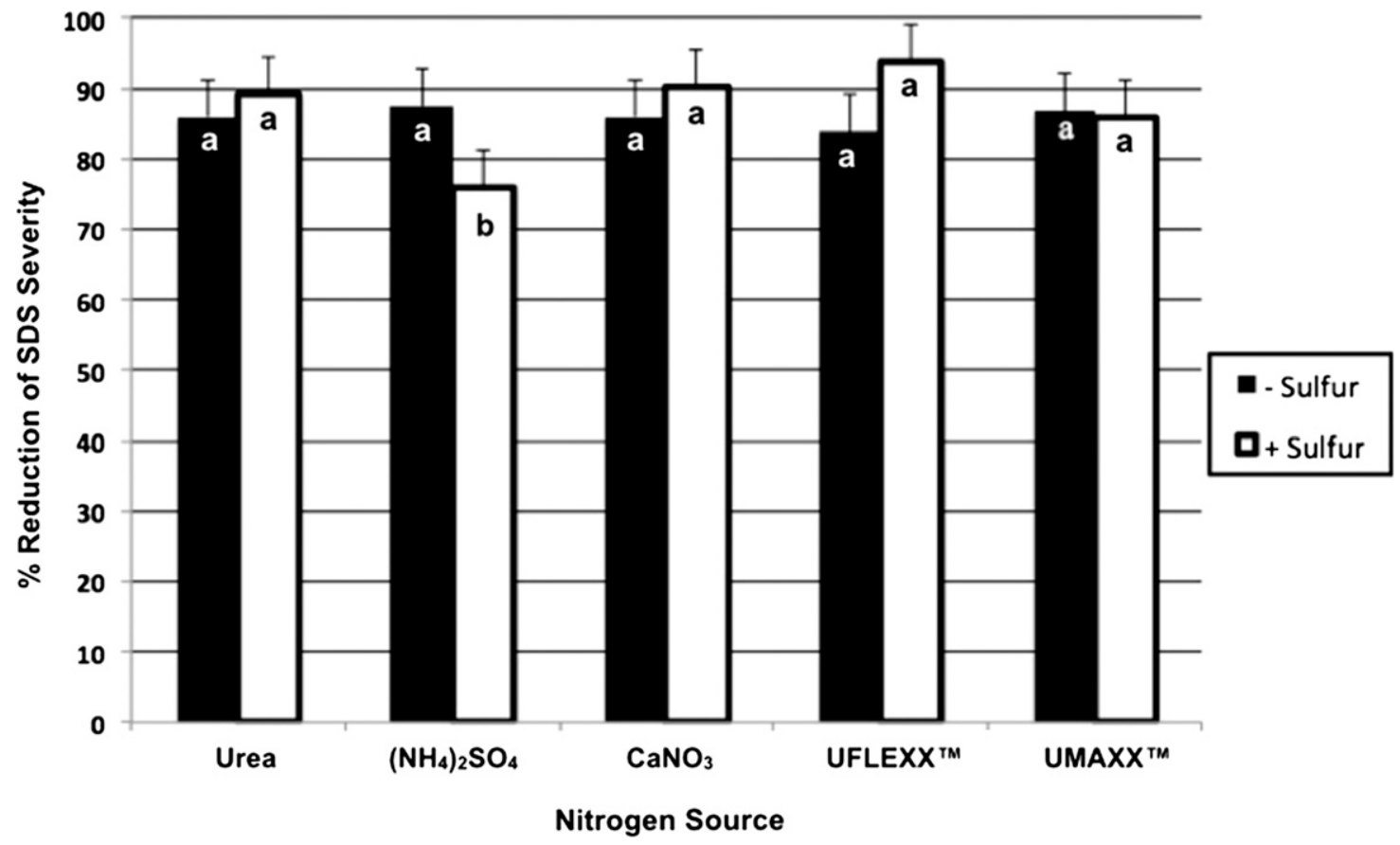

Fig. 5. Effect of nitrogen source and sulfur on the percent reduction of spring dead spot severity caused by Ophiosphaerella herpotricha on 23 May 2013. Percent reduction of spring dead spot severity was calculated as $Y_{0}{ }^{*}-Y_{i} / Y_{0}$, where $Y_{i}$ = disease severity (percent green tissue) assessed by digital image analysis on 23 May 2013 and $Y_{0}=$ disease severity on 10 June 2011, before the trial was initiated. Columns with the same letter are not statistically different according to Tukey's test $(\alpha=0.05)$. Least square means were averaged across all nitrogen source and sulfur treatments. Error bars represent the standard error of the mean.

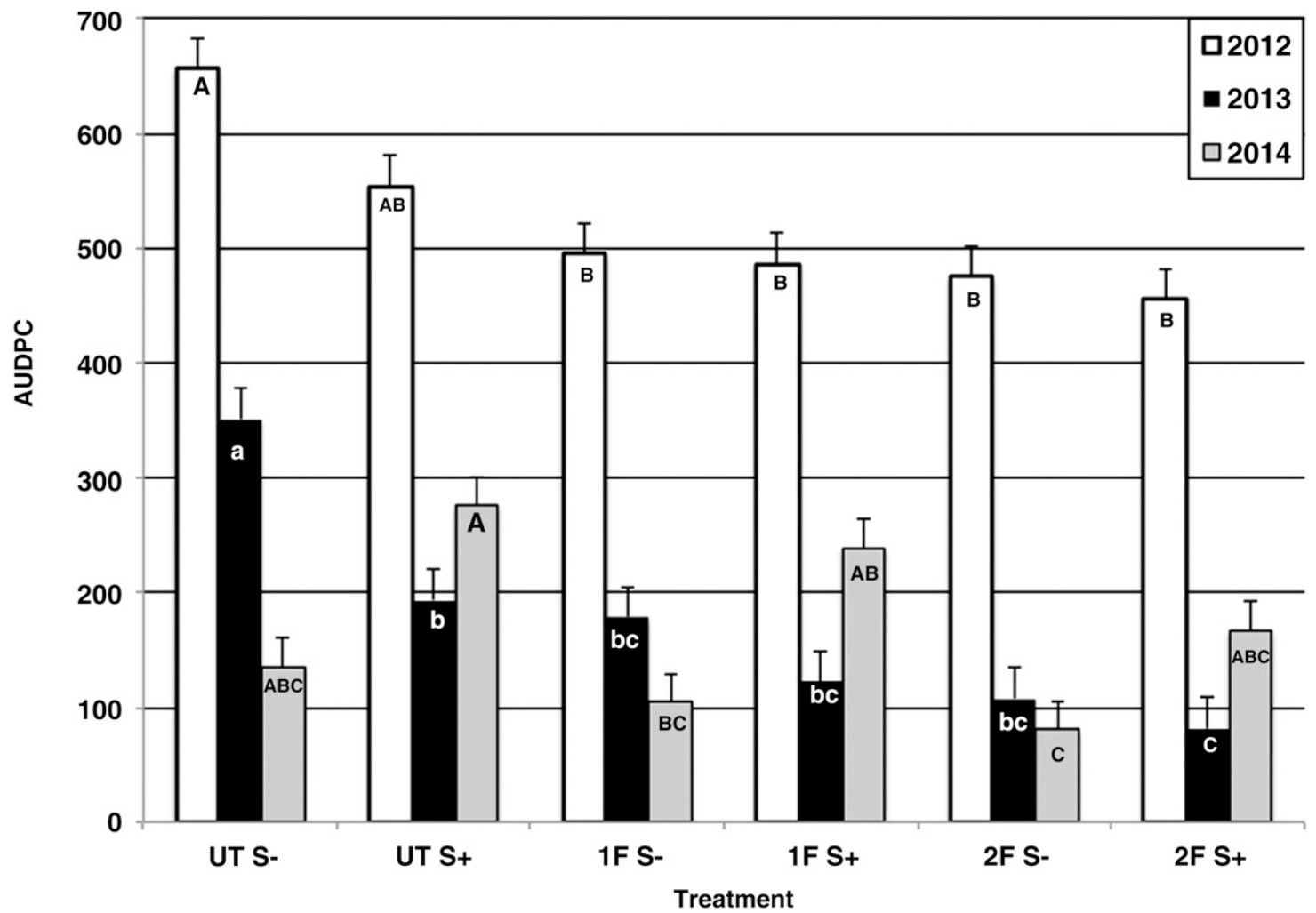

Fig. 6. Effect of nitrogen source and sulfur on area under the disease progress curve (AUDPC) values derived from digital image analysis assessments of spring dead spot caused by Ophiosphaerella herpotricha. AUDPC was calculated with the trapezoidal rule (Shaner and Finney 1977). UT = no fungicide treatment, $1 \mathrm{~F}=$ one fall application of tebuconazole $\left(0.28 \mathrm{~kg}\right.$ a.i. ha $\left.{ }^{-1}\right)$ per year on 14 October, $2 \mathrm{~F}=$ two fall applications of tebuconazole $\left(0.28 \mathrm{~kg}\right.$ a.i. ha $\left.{ }^{-1}\right)$ per year on 16 September and 14 October, $\mathrm{S}-=$ no sulfur treatment, and $\mathrm{S}+=$ sulfur applied annually as flowers of sulfur at $98 \mathrm{~kg} \mathrm{ha}^{-1}$ in June, July, and August. Columns with the same letter within each year are not statistically different according to Tukey's test $(\alpha=0.05)$. Least square means were averaged across all fungicide and sulfur treatments. Error bars represent the standard error of the mean. 
was detected between one and two fall applications per year (Fig. 6).

\section{Discussion}

Based on sequences of the ITS region, O. herpotricha was the predominant spring dead spot pathogen detected in Missouri and the surrounding region. This geographic region has been suggested as a native region for this Ophiosphaerella sp., which would explain its high frequency of isolation (Wetzel et al. 1999b). On occasion, O. korrae was also isolated from infected bermudagrass tissue, indicating an overlapping species distribution. O. herpotricha and $O$. korrae have previously been isolated from the same location and may even be isolated from the same tissue sample (Wetzel et al. 1999b). O. narmari was isolated from a single spring dead spot sample obtained from a 1-year-old Patriot bermudagrass block vegetatively propagated the previous year with plant material imported from Oklahoma. Therefore, this pathogen species is likely not widely distributed in Missouri but may be introduced occasionally with distributed plant material.

$O$. herpotricha is considered the most aggressive of the three spring dead spot pathogen species (Tredway et al. 2009b) and, in this study, was isolated from 13 different cultivars. Large spring dead spot outbreaks were observed on cold-tolerant cultivars such as Patriot and Riviera, suggesting that cold-tolerant cultivars are also susceptible to spring dead spot pathogen infection. More research is needed to screen the susceptibility of new bermudagrass cultivars to spring dead spot, and determine whether host susceptibility varies among spring dead spot species or climactic region.

Previous research indicates that nitrogen source or soil $\mathrm{pH}$ may play an important role in suppressing spring dead spot. Field studies report a decrease in spring dead spot symptoms when bulk soil $\mathrm{pH}$ is reduced below 5.5 (Dernoeden et al. 1991; Vincelli 2014). However, $O$. herpotricha and $O$. korrae grew well at $\mathrm{pH} 5$ and higher in our in vitro study. Maintaining a bulk soil $\mathrm{pH}$ below 5 would be challenging and may lead to nutrient deficiencies but only the rhizosphere $\mathrm{pH}$ may need this level of acidity during the infection period, which may occur along the root surface when ammonium ions are acquired. Accurately separating and comparing bulk and rhizosphere $\mathrm{pH}$ in plants possessing a fibrous root system is difficult but may need to be determined to fully understand the $\mathrm{pH}$ interaction with the spring dead spot pathogen (Youssef and Chino 1989).

No difference was detected among $O$. herpotricha and $O$. korrae in their in vitro response to calcium nitrate or ammonium sulfate concentrations, because both grew equally well on calcium nitrate and poorly on ammonium sulfate. Hacskaylo et al. (1954) performed a similar liquid mycelial growth assay and found ammonium sulfate to be a preferred nitrogen source over calcium nitrate for 24 of 25 fungal species. However, this result only occurred when fumaric acid was used to buffer treatment $\mathrm{pH}$. When fumaric acid was not used as a buffer, $\mathrm{pH}$ in ammonium sulfate treatments decreased, which the authors hypothesize negatively affected growth. A similar mechanism of ammonium uptake is known to occur in fungal mycelium that results in $\mathrm{pH}$ reduction (Morton and Macmillan 1954). Repeating these assays using a treatment $\mathrm{pH}$ buffer may be appropriate to demonstrate nitrogen form preference for growth among these Ophiosphaerella spp.

Contrary to previous reports, our field study did not indicate a reduction in spring dead spot severity from nitrogen source. Dernoedon et al. (1991) observed that ammonium sulfate applications reduced spring dead spot caused by $O$. korrae in Maryland. $O$. herpotricha, which is considered to be more aggressive than $O$. korrae, was the only spring dead spot species found in this field plot, which may explain the difference between these results. In North Carolina, ammonium sulfate was demonstrated to suppress spring dead spot caused by O. herpotricha (Tredway et al. 2009a). The different soil type or region may be responsible for this difference in results. Soil $\mathrm{pH}$ at our site was initially low (approximately 5.5), and perhaps the affect of ammonium sulfate application on rhizosphere $\mathrm{pH}$ was not as prevalent. Irrigation water $\mathrm{pH}$ at our research site was also slightly alkaline (pH 7.5 to 8), which may have reduced the potential for soil $\mathrm{pH}$ reduction from ammonium nitrogen forms. Finally, and perhaps most importantly, this study was conducted on a site with a widespread spring dead spot epidemic caused by $O$. herpotricha, whereas the previous study was performed on inoculated plots evaluating preventive fertility treatments. After infection, O. herpotricha colonizes the root cortex of susceptible cultivars (Caasi et al. 2010) and may not need to reinfect the plant from the root surface every year to reproduce symptoms. Therefore, changing rhizosphere $\mathrm{pH}$ with a nitrogen source may have a reduced effect or require a multiyear integrated control strategy.

Sulfur applications resulted in a reduction in spring dead spot severity similar to a single fungicide application applied without sulfur in 2013. Sulfur applications have the potential to lower soil $\mathrm{pH}$; however, no considerable differences were detected in bulk soil $\mathrm{pH}$ in sulfur-treated plots in this study. A low initial soil $\mathrm{pH}$, the buffering capacity of the soil, or the alkaline $\mathrm{pH}$ of the irrigation water could have prevented soil acidification by the sulfur applications. As opposed to soil acidification, sulfur applications may also be directly inhibiting the pathogen by acting as a fungicide (McCallan 1949). Delayed spring greenup and premature winter dormancy were observed in plots receiving sulfur beginning in spring and fall 2013. This effect was exacerbated in plots also treated with ammonium sulfate; therefore, sulfur rates may need to be decreased or discontinued to decrease the possibility of this effect. This observation of delayed spring greenup is in agreement with previous research (Vincelli 2014).

After 1 year, one or two fall fungicide applications reduced disease compared with the untreated plots but control was still unacceptable. Therefore, 2 years of fungicide applications may be necessary to achieve desirable control levels. Additionally, one fungicide application per annum provided statistically as much control as two fungicide applications per annum in all 3 years of the study. Therefore, one application may be more cost effective in a multiyear management system. Conversely, Walker (2009) reported an $81 \%$ reduction in spring dead spot symptoms after 1 year with two fall applications of propiconazole. This difference in fungicide efficacy may stem from the different active ingredient used, or from the higher volume of post-application irrigation (10 to $13 \mathrm{~mm}$ ) used for fungicide delivery in the previous research.

This research indicates curative management of spring dead spot can be achieved through a multiyear integrated strategy combining sulfur and fungicide applications. Future research integrating reduced sulfur rates to minimize plant side effects, cultivation practices, and fungicide application timing and methods is needed to develop management recommendations aimed toward reducing fungicide requirements and increasing control efficacy.

\section{Acknowledgments}

This research was supported with funding from the Ozark Turfgrass Association and Mississippi Valley Golf Course Superintendents Association. We thank B. Fresenburg and R. Kremer for review and constructive comments, M. Ellerseick for statistical advice, K. Robertson for valuable technical assistance, and L. P. Tredway and E. L. Butler (North Carolina State University) for providing fungal isolates from their collections.

\section{Literature Cited}

Alscher, R. G., Erturk, N., and Heath, L. S. 2002. Role of superoxide dismutases (SODs) in controlling oxidative stress in plants. J. Exp. Bot. 53:1331-1341.

Brown, P., Graham, R. D., and Nicholas, D. J. 1984. The effects of manganese and nitrate supply on the levels of phenolics and lignin in young wheat plants. Plant Soil 81:437-440.

Butler, E. L., and Tredway, L. P. 2006. Methods and timing of fungicide applications for control of spring dead spot in hybrid bermudagrass. Online publication. Plant Health Prog. doi:10.1094/PHP-2006-0901-01-RS.

Caasi, O. C., Walker, N. R., Marek, S. M., Enis, J. N., and Mitchell, T. K. 2010. Infection and colonization of turf-type bermudagrass by Ophiosphaerella herpotricha expressing green or red fluorescent proteins. Phytopathology 100:415-423.

Crahay, J., Dernoeden, P., and O'Neill, N. 1988. Growth and pathogenicity of Leptosphaeria korrae in bermudagrass. Plant Dis. 72:945-949.

Dernoeden, P. H., Crahay, J. N., and Davis, D. B. 1991. Spring dead spot and bermudagrass quality as influenced by nitrogen source and potassium. Crop Sci. 31:1674-1680.

Endo, R. M., Ohr, H. D., and Krausman, E. M. 1985. Leptosphaeria korrae, a cause of spring dead spot of bermudagrass in California. Plant Dis. 69:235-237. 
Gardes, M., and Bruns, T. D. 1993. ITS primers with enhanced specificity for basidiomycetes- application to the identification of mycorrhizae and rusts. Mol. Ecol. 2:113-118.

Hacskaylo, J., Lilly, V. G., and Barnett, H. L. 1954. Growth of fungi on three sources of nitrogen. Mycologia 46:691-701.

Heckman, J., Murphy, J., and Clarke, B. 2003. Optimizing manganese fertilization for the suppression of take-all patch disease on creeping bentgrass. Crop Sci. 43:1395-1398

Henrion, B., Le Tacon, F., and Martin, F. 1992. Rapid identification of genetic variation of ectomycorrhizal fungi by amplification of ribosomal RNA genes. New Phytol. 122:289-298.

Hill, W., Heckman, J., Clarke, B. B., and Murphy, J. A. 1999. Take-all patch suppression in creeping bentgrass with manganese and copper. HortScience 34:891-892.

Hill, W. J., Heckman, J. R., Clarke, B. B., and Murphy, J. A. 2003. Summer patch disease severity on Kentucky bluegrass in response to fertilizer source. J. Plant Nutr. 26:1499-1512.

Iriarte, F. B., Wetzel, H. C., Fry, J. D., Martin, D. L., and Tisserat, N. A. 2004. Genetic diversity and aggressiveness of Ophiosphaerella korrae, a cause of spring dead spot of bermudagrass. Plant Dis. 88:1341-1346.

Karcher, D. E., and Richardson, M. D. 2003. Quantifying turfgrass color using digital image analysis. Crop Sci. 43:943-951.

Karcher, D. E., and Richardson, M. D. 2005. Batch analysis of digital images to evaluate turfgrass characteristics. Crop Sci. 45:1536-1539.

Marx, D. H. 1969. The influence of ectotrophic mycorrhizal fungi on the resistance of pine roots to pathogenic infections. Phytopathology 59:153-163.

McCallan, S. E. A. 1949. The nature of the fungicidal action of copper and sulfur. Bot. Rev. 15:629-643.

McCarty, L. B., Lucas, L. T., and DiPaola, J. M. 1992. Spring dead spot occurrence in bermudagrass following fungicide and nutrient applications. HortScience 27: 1092-1093.

Morton, A. G., and Macmillan, A. 1954. The assimilation of nitrogen from ammonium salts and nitrate by fungi. J. Exp. Bot. 5:232-252.

Mosdell, D., Daniel, W., and Freeborg, R. 1986. Evaluation of dicyandiamideamended fertilizers on Kentucky bluegrass. Agron. J. 78:801-806.

Shaner, G., and Finney, R. 1977. The effect of nitrogen fertilization on the expression of slow-mildewing resistance in Knox wheat. Phytopathology 67: 1051-1056.

Smiley, R., and Cook, R. 1973. Relationship between take-all of wheat and rhizosphere $\mathrm{pH}$ in soils fertilized with ammonium vs. nitrate-nitrogen. Phytopathology 63:882-890.
Soltanpour, P. N., Johnson, G. W., Workman, S. M., Jones, J. B., Jr., Miller, R. O. 1996. Inductively coupled plasma emission spectrometry and inductively coupled plasma-mass spectrometry. Pages 91-140 in: Methods of Soil Analysis-Part 3. Chemical Methods. S. L. Sparks, A. L. Page, P. A. Helmke, R. H. Loeppert, P. N. Soltanpour, and M. A. Tabaitabai, eds. Soil Science Society of America, Madison, WI

Tamura, K., Peterson, D., Stecher, G., Nei, M., and Kumar, S. 2011. MEGA5 Molecular evolutionary genetics analysis using maximum likelihood, evolutionary distance and maximum parsimony methods. Mol. Biol. Evol. 28:2731-2739.

Thompson, D. C., Clarke, B. B., and Heckman, J. R. 1995. Nitrogen form and rate of nitrogen and chloride application for the control of summer patch in Kentucky bluegrass. Plant Dis. 79:51-56.

Tisserat, N. A., Pair, J. C., and Nus, A. 1989. Ophiosphaerella herpotricha, a cause of spring dead spot of bermudagrass in Kansas. Plant Dis. 73:933-937.

Tredway, L. P., Soika, M. D., and Butler, E. L. 2009a. Response of spring dead spot caused by Ophiosphaerella korrae and $O$. herpotricha to fertilization programs and preventive fungicide applications. (Abstr.) Phytopathology 99:S129.

Tredway, L. P., Tomaso-Peterson, M., Perry, H., and Walker, N. R. 2009b. Spring dead spot of bermudagrass: A challenge for researchers and turfgrass managers. Online publication. Plant Health Prog. doi:10.1094/PHP-2009-0710-01-RV.

Vincelli, P. 2014. Managing spring dead spot of bermudagrass. Online publication http://www2.ca.uky.edu/agcollege/plantpathology/ext_files/PPFShtml/PPFSOR-T-13.pdf

Walker, J., and Smith, A. M. 1972. Leptosphaeria namari and L. korrae spp. nov., two long spored pathogens in Australia. Trans. Br. Mycol. Soc. 58:459-466, IN11-IN12.

Walker, N. R. 2009. Influence of fungicide application timings on the management of bermudagrass spring dead spot caused by Ophiosphaerella herpotricha. Plant Dis. 93:1341-1345.

Walker, N. R., Mitchell, T. K., Morton, A. N., and Marek, S. M. 2006. Influence of temperature and time of year on colonization of bermudagrass roots by Ophiosphaerella herpotricha. Plant Dis. 90:1326-1330.

Wetzel, H. C., III, Hulbert, S. H., and Tisserat, N. A. 1999a. Molecular evidence for the presence of Ophiosphaerella narmari n. comb., a cause of spring dead spot of bermudagrass, in North America. Mycol. Res. 103:981-989.

Wetzel, H. C., III, Skinner, D. Z., and Tisserat, N. A. 1999b. Geographic distribution and genetic diversity of three Ophiosphaerella species that cause spring dead spot of bermudagrass. Plant Dis. 83:1160-1166.

Youssef, R. A., and Chino, M. 1989. Root-induced changes in the rhizosphere of plants. I. pH changes in relation to the bulk soil. Soil Sci. Plant Nutr. 35:461-468. 